\title{
Toxicity Assessment of Municipal Solid Waste Landfill Leachate Collected in Different Seasons from Okhala Landfill Site of Delhi
}

\author{
Anshu Gupta, Paulraj Rajamani* \\ School of Environmental Sciences, Jawaharlal Nehru University, New Delhi, India \\ Email: *paulrajr@hotmail.com
}

Received 27 April 2015; accepted 8 June 2015; published 11 June 2015

Copyright (C) 2015 by authors and Scientific Research Publishing Inc.

This work is licensed under the Creative Commons Attribution International License (CC BY). http://creativecommons.org/licenses/by/4.0/

(c) (i) Open Access

\section{Abstract}

Recent studies of leachate induced toxicity have mainly focused on crude leachates collected once from the landfill site, while little attention has been paid to the changes in toxicity resulting from the varying leachate concentration with respect to seasonal variation. The present study deals with the toxicological effects of municipal landfill leachate on Vicia faba. Leachate samples were collected in different seasons (summer, monsoon and winter) and toxicity study was performed via various parameters like germination inhibition, growth, chlorophyll content, lipid peroxidation and activities of antioxidant enzymes. The results show that landfill leachate of all three seasons promoted the growth and chlorophyll content at lower doses for short exposure time but at the higher doses there was inhibition of growth as well as reduction in the chlorophyll content. There was a dose dependent elevation in the malondialdehyde (MDA) level and inhibited antioxidant enzyme activities. The physiological responses varied as a function of leachate concentration which was further dependent on the season of leachate collection. Therefore, this study suggests that the leachate collected in all the three seasons is toxic and may pose a health effect to the general public directly or indirectly. It also suggests that the most important aspect for the treatment of landfill leachate is controlling its concentration which varies with respect to the seasons of leachate collection.

\section{Keywords}

Landfill Leachate, Toxicity, Seasonal Variation, Inhibition, Health Effects

\footnotetext{
"Corresponding author.
} 


\section{Introduction}

Landfills are the primary option for the disposal of Municipal solid waste (MSW) all over the world but most of these landfills are non-engineered which can't prevent the contamination of the soil and ground water by the toxic leachate produced [1]. The decomposition of solid waste in the landfill, along with rainwater penetration is responsible for the formation of a dark liquid with unpleasant odour known as leachate [2] [3]. The general composition of landfill leachate is very complex; it is known to be rich in metals, ammonia, organic compounds and other toxicants that may be of great concern for the aquatic environment [4]. High organic matter in the landfill leachate is generated due to the penetration of precipitation through the waste that leads to the biodegradation [5]. It has been reported previously that toxic and carcinogenic chemicals are present in the leachates of MSW landfills [6]. MSW landfills that are mostly present in the urban areas pollute ground and surface water which causes problems to the environment and pose risk to human health [4] [7]-[10].

In large parts of Asia, landfill characteristics are influenced by the monsoon climate, which includes the characteristic differences between the rainy season and dry seasons. Leachate in dry season is concentrated because of the evaporation where as in the rainy season, large amount of leachate is produced with low concentration [11] [12]. For the proper and efficient operation of leachate treatment, evaluation of seasonal variation plays an important role [13] [14].

The toxicity is generally determined based on its physicochemical properties, with ammonia, chemical oxygen demand (COD) and heavy metals being identified as the major contributors [15]. In contrast to chemical analysis alone, bioassays can be used to characterize the toxicological effects of the municipal solid waste leachates that would integrate the biological effects of all the constituents of the leachates. Thus, with the help of bioassays, bioavailability, synergistic, antagonistic, additive affects of the constituents of the leachate can be assessed directly without going for assumptions and extrapolations made from chemical analysis alone [7]. Cytogenetic abnormalities and DNA damage induced by MSW Leachate implicate that humans consuming leachate contaminated water are at risk of developing adverse health consequences. Therefore, it is an important task to monitor the toxic potential of MSW landfill leachate [16].

Previous studies reported that leachate induces eco-toxicity. However less attention has been paid to the toxicity induced due to seasonal variations in the leachate composition. Present study has been aimed to estimate the toxicity of leachate collected in different seasons. Higher plants provide a useful genetic system for screening and monitoring of environmental pollutants. Mutagenic activity of chemicals has been analysed with different plant systems such as Allium cepa, Vicia faba, Hordeum vulgare [17]. Previously, Sang and Li, [17] have reported that in the root tips of Vicia faba treated with landfill leachate, there was a significant increase in the micronucleus (MN) frequencies and anaphase aberration (AA) frequencies in a concentration dependent manner. Various studies have shown that legume crops are very responsive to leachates in terms of growth and seed germination [18]. As Vicia faba belongs to the legume family, for this reason, in the present study the toxicity of landfill leachate has been investigated with Vicia faba bioassay.

\section{Material and Methods}

\subsection{Landfill Site}

The Okhala landfill is in operation since 1994. The expected life span of Okhala landfill was till 1997-1998 but the garbage is being dumped into the landfill even now. It is located in the south of Delhi, which is in proximity to the heavily populated residential area and is one of the biggest industrial areas in close proximity to the Yamuna river bank (Figure 1). Approximately $1200 \mathrm{~T} /$ day is dumped into the landfill. The waste disposed in the landfill includes domestic waste consisting of kitchen waste, paper, plastic, glass, cardboard, cloths, construction and unauthorised industrial waste.

\subsection{Landfill Leachate Sample Collection and Analysis}

According to multi-spot collection principle [19], the leachate samples were collected from different points of the landfill, mixed and sealed in bottles and transported to laboratory for further analysis without any delay. Samples were collected in three different seasons (Summer, Monsoon and Winter) from the Okhala landfill site. $\mathrm{pH}$, Electrical conductivity (EC), Total dissolved solids (TDS) were measured in the field without any delay by water analysis kit (PC-510, Eutech Instruments). Basic physicochemical properties of the leachate samples col- 


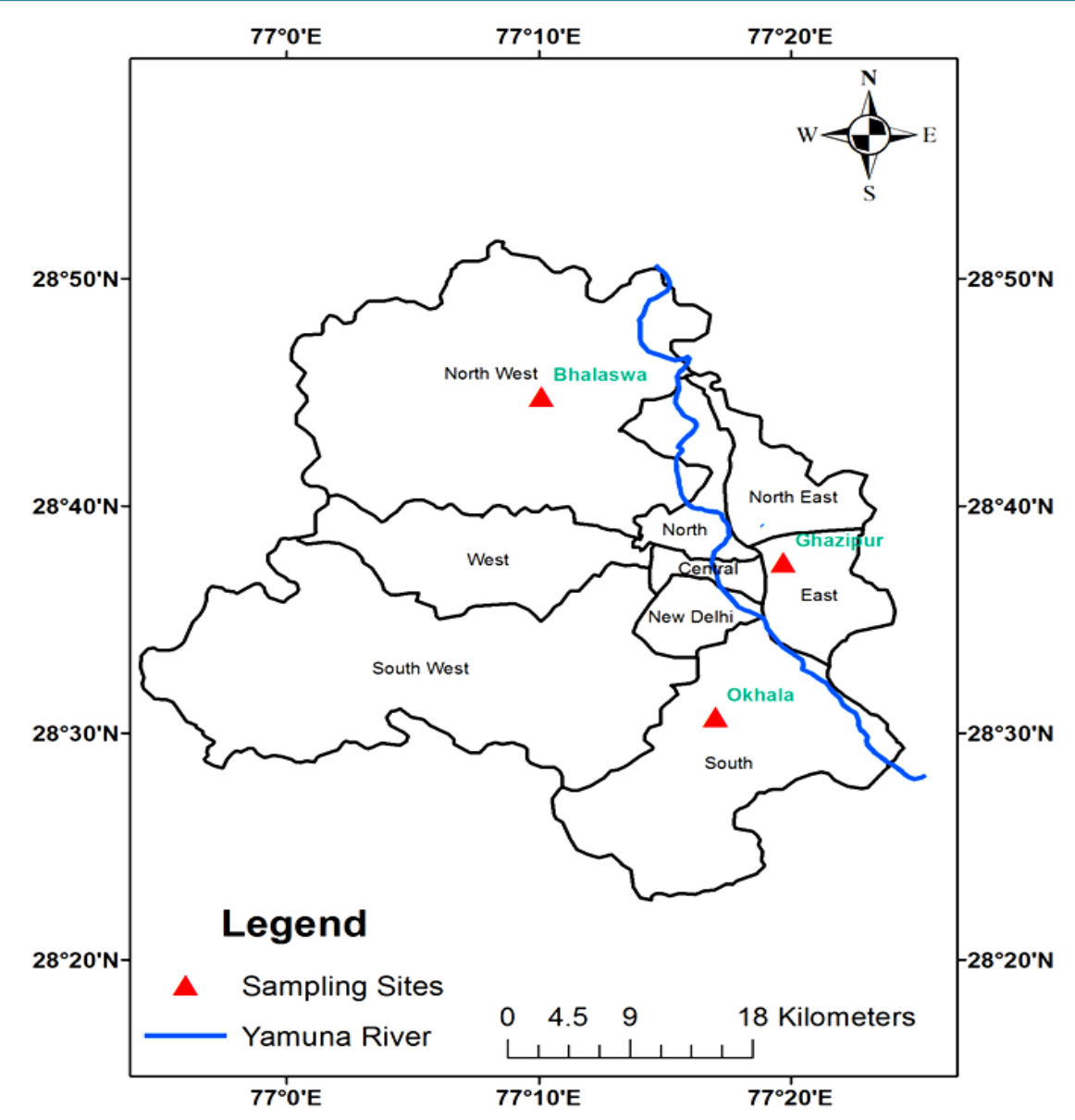

Figure 1. Showing the three major landfill sites in Delhi.

lected in different seasons were analysed according to Standard methods [20]. Metals were analysed by Atomic absorption spectrophotometer (Thermo Scientific). Chemical oxygen demand (COD) was measured by the potassium dichromate oxidation method, Biochemical oxygen demand (BOD) was measured by a 5-day BOD test (APHA). Ammonia concentration was measured by ammonia selective electrode.

\subsection{Plant Material Used}

Dry seeds of Vicia faba were supplied by the Indian Agricultural Research Institute (IARI), Pusa, New Delhi. The seeds were soaked for $10 \mathrm{~h}$ in distilled water and then allowed to germinate on moist germination sheets. The experiment has been conducted in an incubator at $(25 \pm 1)^{\circ} \mathrm{C}$ under a dark/light cycle $(14 \mathrm{~h}: 10 \mathrm{~h})$ in three replicates to minimize the experimental errors.

\subsection{Germination and Growth}

Six experimental groups were taken with sixty seeds in each group. Five groups $(6.25 \%, 12.5 \%, 25 \%, 50 \%$ and $100 \%)$ were subsequently exposed to different concentrations of leachates by diluting the crude leachate with distilled water while the negative control group was exposed to distilled water. The germination ratio of 60 seeds in each treatment was measured after exposure for 24,48 and $72 \mathrm{~h}$. Thirty seedlings which reached $1.4 \mathrm{~cm}$ root length were treated for $120 \mathrm{~h}$, and seminal root and shoot length were measured after every $24 \mathrm{~h}$. Moreover, the leaves were simultaneously harvested after 5-days treatment for further tests.

\subsection{Chlorophyll Estimation}

Chlorophyll content was measured according to Sang et al. [21]. In brief, fresh leaves samples (0.1 g) were pul- 
verized with distilled water and the homogenate was extracted using $80 \%$ acetone. Absorbance of the supernatant was measured at 663 and $645 \mathrm{~nm}$ using spectrophotometer (Shimadzu 10109). The content of chlorophyll a (Chl $a$ ) was calculated using the formula Chl $a=12.7 \mathrm{~A}_{663}-2.69 \mathrm{~A}_{645}$. The content of chlorophyll b (Chl b) was calculated using the formula $C h l b=22.9 \mathrm{~A}_{645}-4.68 \mathrm{~A}_{663}$. The results were expressed as mg/g FW (fresh weight).

\subsection{Estimation of Lipid Peroxidation}

The level of lipid peroxidation was estimated by measuring the concentration of malondialdehyde (MDA). MDA is a common product of lipid peroxidation and is a sensitive diagnostic index of oxidative injury [22] [23]. In brief, fresh leaf sample (1 g) was ground in 5\% trichloroacetic acid (W/V) and the homogenate was centrifuged at $4000 \mathrm{~g}$ for $10 \mathrm{~min}$. The supernatant fraction was added to an equal volume of $0.6 \%$ thiobarbituric acid $(\mathrm{W} / \mathrm{V})$. The mixture was heated at $100^{\circ} \mathrm{C}$ for $10 \mathrm{~min}$ and then centrifuged at $3000 \mathrm{~g}$ for $10 \mathrm{~min}$ after it was cooled. The absorbance of the supernatant was measured at $532 \mathrm{~nm}$ and lipid peroxidation level was expressed as nmol MDA/g FW (fresh weight).

\subsection{Measurement of Antioxidant Enzyme Activity}

SOD activity was measured by Nitro Bluetetrazolium (NBT) spectrophotometry [24]. In brief, fresh leaf sample (0.5 g) was homogenised in phosphate buffer (0.05 M, pH 7.8) and the homogenate was centrifuged at $1000 \mathrm{~g}$ for $20 \mathrm{~min}$ at $4^{\circ} \mathrm{C}$. The supernatant was added to the reaction mixture, containing $130 \mathrm{mM} \mathrm{DL}-\mathrm{methionine} \mathrm{(Met),}$ $750 \mu \mathrm{M}$ NBT, $100 \mu \mathrm{M}$ EDTA-Na ${ }_{2}$ and $20 \mu \mathrm{M}$ Lactoflavin, in order to determine the absorbance at $560 \mathrm{~nm}$. Inhibition of $50 \%$ of the reaction was defined as one unit of enzyme and the enzyme activity was expressed as U/g FW.

Catalase (CAT) activity was assayed according to the method of Zhang [25], with slight modifications. In brief, fresh leaf sample $(0.25 \mathrm{~g})$ was homogenised in phosphate buffer $(0.2 \mathrm{M}, \mathrm{pH} 7.8)$ containing $1 \%$ polyvinylpyrrolidone K30. The homogenate was centrifuged at $4000 \mathrm{~g}$ for $15 \mathrm{~min}$ at $4{ }^{\circ} \mathrm{C}$ and the supernatant was used for the enzyme assay. CAT activity was examined by measuring the decrease of absorbance at $240 \mathrm{~nm}$ in a reaction mixture containing $0.3 \mathrm{ml} \mathrm{H} \mathrm{O}_{2}(0.1 \mathrm{M})$ and $0.1 \mathrm{ml}$ extract. Results were expressed as U/min/g Fw.

\subsection{Statistical Analysis}

Results are presented as the mean \pm SD. The statistical difference (0.05) among the negative control and a series of treated groups was analyzed using one-way analysis of variance (ANOVA). We used Graph pad prism software package for all statistical analyses.

\section{Results}

\subsection{Properties of Landfill Leachate Samples}

Basic chemical properties of the leachates are presented in Table 1. The 5-day Biochemical Oxygen Demand $\left(\mathrm{BOD}_{5}\right)$ and Chemical Oxygen Demand (COD) were beyond the permissible levels (50 mg/L and $250 \mathrm{mg} / \mathrm{L} \mathrm{re}-$ spectively) as per Gazette of India [26] in all the three seasons, which showed high organic strength of the leachates. Both $\mathrm{BOD}_{5}$ and $\mathrm{COD}$ were high in the summer season. Heavy metals including $\mathrm{Cr}$ and $\mathrm{Pb}$ were found beyond the permissible limits $(2.0 \mathrm{mg} / \mathrm{L}$ and $0.1 \mathrm{mg} / \mathrm{L}$ respectively) [26]. The concentration of ammonical nitrogen was very high in the leachates; this is due to the process of deamination of amino acids during decomposition of organic compounds. Ammonical nitrogen is considered as a major toxicant to living organisms and it was beyond permissible level $(50 \mathrm{mg} / \mathrm{L})$ in the leachates collected in all three seasons. High concentrations of Chloride (permissible level $1000 \mathrm{mg} / \mathrm{L}$ ) and Sulphate were also found in the leachates.

\subsection{Germination}

In the present study it was observed that leachate collected during summer season showed the reduced seed germination as compared to the monsoon and winter season. In summer season, the seed germination was decreased to $4.44 \%$ at $25 \%$ of leachate treatment and total inhibition was observed at $50 \%$ and $100 \%$ of treatment after $72 \mathrm{~h}$ of exposure. Whereas in the leachate collected in monsoon season it decreased up to 30.56\% and 5\% of control at $50 \%$ and $100 \%$ concentrations of leachates after 72 h of exposure. Similarly, in the leachate col- 
lected during winter season the germination was reduced up to $11.11 \%$ and $3.3 \%$ of control at $50 \%$ and $100 \%$ leachate treatment respectively after $72 \mathrm{~h}$ of exposure (Table 2).

\subsection{Early Seedling Growth}

\subsubsection{Root Growth}

A time and dose dependent root length inhibition was observed in all the three seasons with respect to control. During the initial exposure period the root growth was not affected by the lower doses of leachate collected in summer season (Figure 2(a)). With increase in the time of exposure the difference compared to control was significantly augmented, where as crude leachate totally inhibited the root growth.Seeds treated with leachate collected in monsoon, augmentation was observed up to $25 \%$ concentration of leachate and it was inhibited with further increase in the dose of leachate treatment (Figure 2(b)). Similarly a dose dependent inhibition of rootlength was also observed in winter season leachate treated seeds but the root length augmented up to 6.25\% leachate concentration, where as it was inhibted in a time and dose dependent manner with respect to control (Figure 2(c)).

Table 1. Characteristics of the crude leachate sample collected from Okhala Municipal Solid Waste landfill site in summer, monsoon and winter.

\begin{tabular}{cccc}
\hline Parameter & Summer & Monsoon & Winter \\
\hline $\mathrm{pH}$ & 8.1 & 6.8 & 7.9 \\
$\mathrm{EC}(\mu \mathrm{S} / \mathrm{cm})$ & 56,500 & 49,200 & 65,200 \\
$\mathrm{TDS}(\mathrm{mg} / \mathrm{L})$ & 29,580 & 24,100 & 34,800 \\
$\mathrm{BOD}(\mathrm{mg} / \mathrm{L})$ & 2250 & 520 & 1950 \\
$\mathrm{COD}(\mathrm{mg} / \mathrm{L})$ & 13,500 & 2250 & 11,250 \\
$\mathrm{NH}_{3}-\mathrm{N}(\mathrm{mg} / \mathrm{L})$ & 2175 & 480 & 1875 \\
$\mathrm{~Pb}(\mathrm{mg} / \mathrm{L})$ & 9.5 & 0.88 & 3.8 \\
$\mathrm{Cr}(\mathrm{mg} / \mathrm{L})$ & 11.9 & 0.45 & 4.5 \\
$\mathrm{Fe}(\mathrm{mg} / \mathrm{L})$ & 125 & 15.7 & 75.5 \\
$\mathrm{Cl}^{-}(\mathrm{mg} / \mathrm{L})$ & 4950 & 1685 & 2850 \\
$\mathrm{SO}_{4}^{2-}(\mathrm{mg} / \mathrm{L})$ & 7250 & 1250 & 6525 \\
\hline
\end{tabular}

Table 2. Effects of Okhala landfill leachate collected in summer, monsoon and winter season on the germination of Vicia faba seeds.

\begin{tabular}{|c|c|c|c|c|c|c|c|c|c|}
\hline \multicolumn{10}{|c|}{ Germination Percentage ( $\% \pm \mathrm{SD})$} \\
\hline \multirow{2}{*}{$\begin{array}{c}\text { Test } \\
\text { Substance }\end{array}$} & \multicolumn{3}{|c|}{24 hrs } & \multicolumn{3}{|c|}{48 hrs } & \multicolumn{3}{|c|}{72 hrs } \\
\hline & Summer & Monsoon & Winter & Summer & Monsoon & Winter & Summer & Monsoon & Winter \\
\hline Control & $94.44 \pm 1.72$ & $95 \pm 1.491$ & $\begin{array}{l}93.89 \% \pm \\
1.72\end{array}$ & $\begin{array}{c}98.33 \pm \\
1.491\end{array}$ & $\begin{array}{c}97.78 \pm \\
0.861\end{array}$ & $\begin{array}{c}97.22 \pm \\
0.860\end{array}$ & 100 & $99.44 \pm 0.861$ & $\begin{array}{c}99.44 \pm \\
0.861\end{array}$ \\
\hline $6.25 \%$ & $50 \pm 2.98^{* * *}$ & $70 \pm 2.98^{* *}$ & $\begin{array}{c}64.44 \% \pm \\
1.49^{* * *}\end{array}$ & $\begin{array}{l}78.89 \pm \\
1.721^{* *}\end{array}$ & $\begin{array}{c}85.55 \pm \\
1.721^{*}\end{array}$ & $\begin{array}{c}82.78 \pm \\
2.78^{*}\end{array}$ & $\begin{array}{c}88.89 \pm \\
2.277^{*}\end{array}$ & $94.44 \pm 1.723$ & $\begin{array}{c}91.66 \pm \\
1.497\end{array}$ \\
\hline $12.5 \%$ & $32.78 \pm .861^{* * *}$ & $51.11 \pm 1.72^{* * *}$ & $\begin{array}{l}56.11 \pm \\
2.28^{* * * *}\end{array}$ & $\begin{array}{l}44.45 \pm \\
2.275^{* * *}\end{array}$ & $\begin{array}{l}82.78 \pm \\
0.861^{*}\end{array}$ & $\begin{array}{l}68.33 \% \pm \\
1.49^{* * *}\end{array}$ & $\begin{array}{l}56.67 \pm \\
1.489^{* * *}\end{array}$ & $88.89 \pm 2.276$ & $\begin{array}{c}82.22 \% \pm \\
2.28^{*}\end{array}$ \\
\hline $25 \%$ & $1.67 \pm 1.491^{* * *}$ & $43.33 \pm 2.58^{* * *}$ & $\begin{array}{l}40 \% \pm \\
2.98^{* * * *}\end{array}$ & $\begin{array}{c}4.44 \pm \\
0.859^{* * * *}\end{array}$ & $\begin{array}{l}55.001 \pm \\
1.492^{* * *}\end{array}$ & $\begin{array}{l}46.67 \pm \\
1.49^{* * *}\end{array}$ & $\begin{array}{c}4.44 \pm \\
0.861^{* * *}\end{array}$ & $\begin{array}{l}63.33 \pm \\
1.491^{* * *}\end{array}$ & $\begin{array}{l}50 \% \pm \\
2.98^{* * *}\end{array}$ \\
\hline $50 \%$ & 0 & $\begin{array}{l}18.33 \pm \\
1.489^{* * *}\end{array}$ & $\begin{array}{l}9.22 \% \pm \\
0.86^{* * *}\end{array}$ & 0 & $\begin{array}{l}27.78 \pm \\
2.277^{* * *}\end{array}$ & $\begin{array}{l}11.11 \% \pm \\
1.72^{* * * *}\end{array}$ & 0 & $\begin{array}{l}30.56 \pm \\
1.72^{* * *}\end{array}$ & $\begin{array}{l}11.11 \pm \\
3.10^{* * *}\end{array}$ \\
\hline $100 \%$ & 0 & $3.33 \pm 1.49^{* * *}$ & $\begin{array}{c}3.33 \pm \\
1.478^{* * *}\end{array}$ & 0 & $5 \pm 1.491^{* * *}$ & $\begin{array}{l}3.33 \% \pm \\
1.478^{* * *}\end{array}$ & 0 & $5 \pm 1.491^{* * *}$ & $\begin{array}{l}3.33 \% \pm \\
1.478^{* * *}\end{array}$ \\
\hline
\end{tabular}




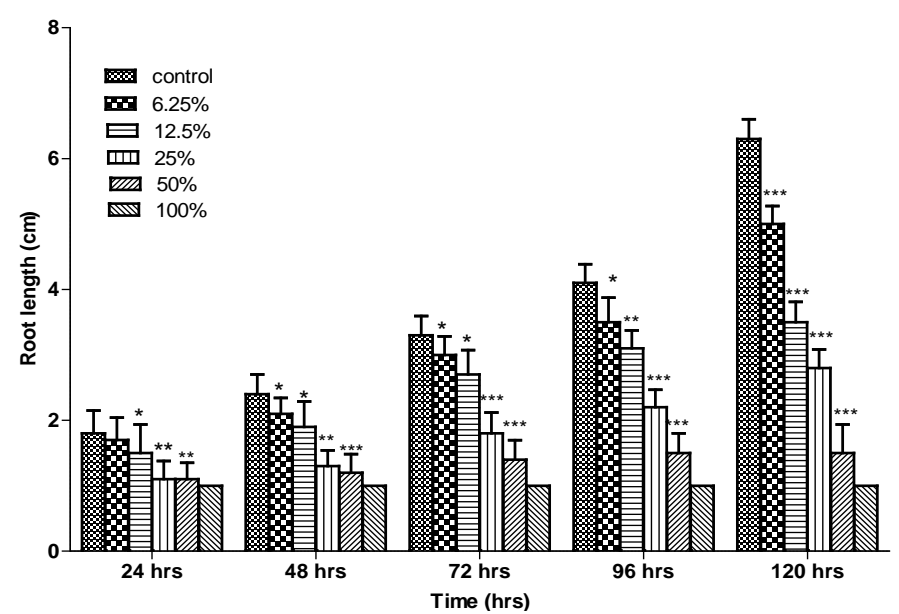

(a)

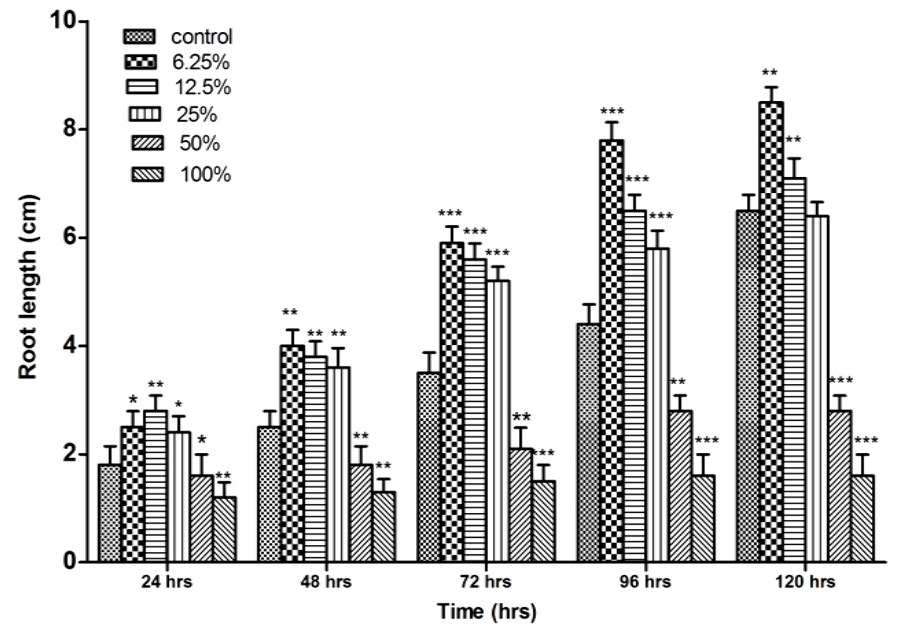

(b)

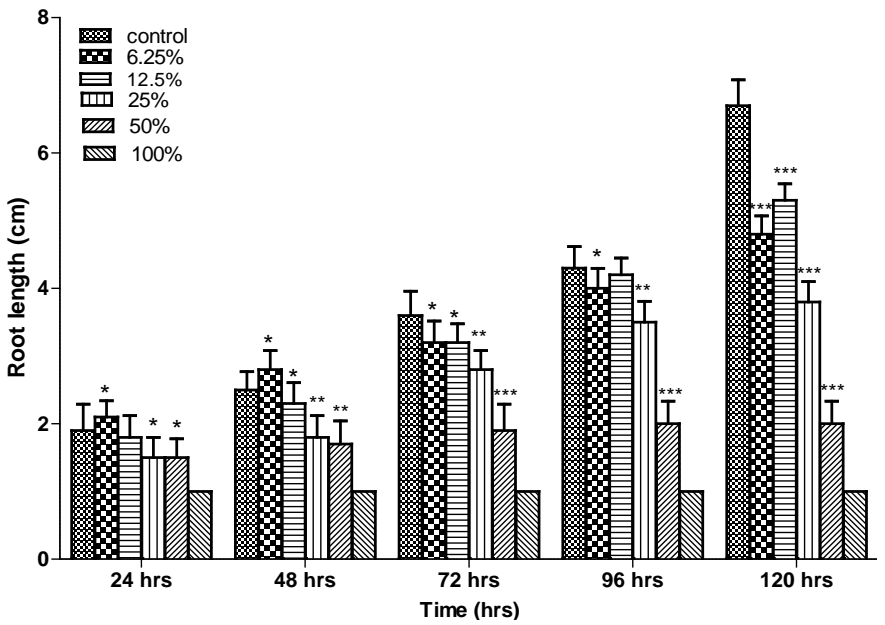

(c)

Figure 2. (a) showing root length of Vicia faba seedlings treated for $120 \mathrm{~h}$ with leachate from Okhala landfill collected in summer season. Data represent the mean $\pm \mathrm{SD}$. ${ }^{*} \mathrm{p}<0.05,{ }^{* *} \mathrm{p}<0.01,{ }^{* * *} \mathrm{p}<0.001$ vs. control. (b) showing root length of Vicia faba seedlings treated for $120 \mathrm{~h}$ with leachate from Okhala landfill collected in monsoon season. Data represent the mean \pm SD. ${ }^{*} \mathrm{p}<0.05,{ }^{* *} \mathrm{p}<0.01,{ }^{* * *} \mathrm{p}<0.001$ vs. control. (c) showing root length of Vicia faba seedlings treated for $120 \mathrm{~h}$ with leachate from Okhala landfill collected in winter season. Data represent the mean $\pm \mathrm{SD}$. ${ }^{*} \mathrm{p}<0.05,{ }^{* *} \mathrm{p}<0.01,{ }^{* * *} \mathrm{p}<0.001$ vs. control. 


\subsubsection{Shoot Elongation}

The shoot growth was not affected much at the lower concentrations of leachate collected in summer and winter season during the first $24 \mathrm{~h}$ of exposure but with the increase in time of treatment the shoot growth was inhibited even at the lower doses as compared to the control group (Figure 3(a) and Figure 3(c)). Total inhibition of shoot length was observed in crude leachate. In the monsoon season the shoot growth was promoted even at the lower leachate concentration and with increase in time of treatment the growth was promoted, but at the higher doses (50\% and 100\%) the shoot growth was inhibited (Figure 3(b)).

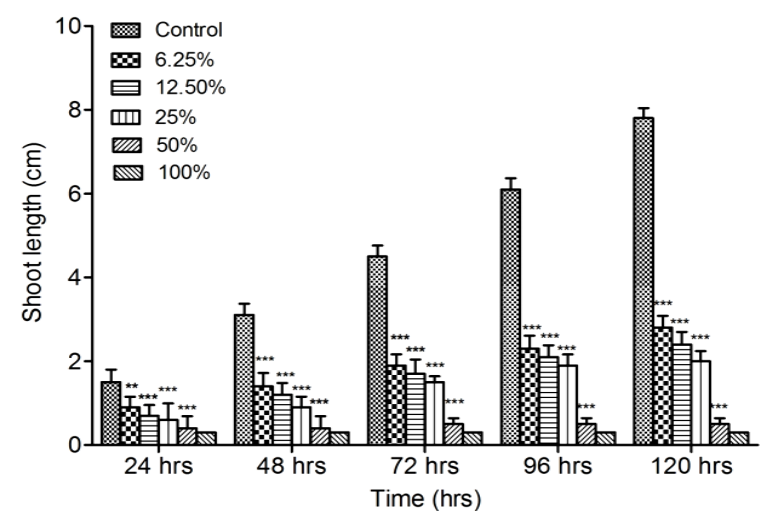

(a)

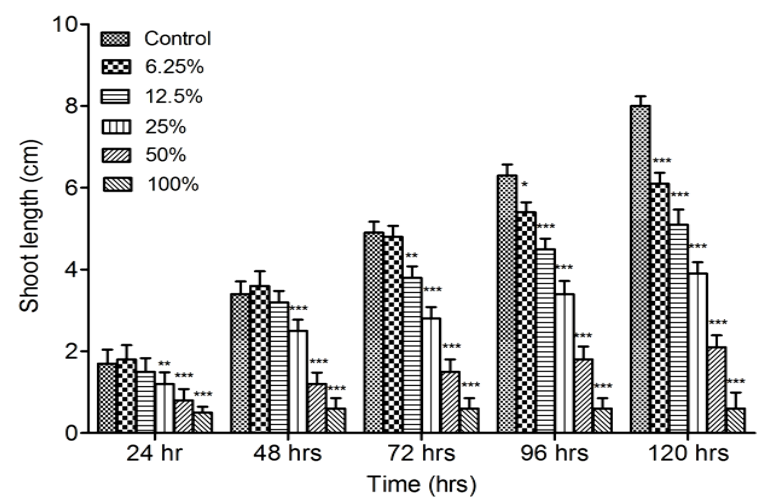

(b)

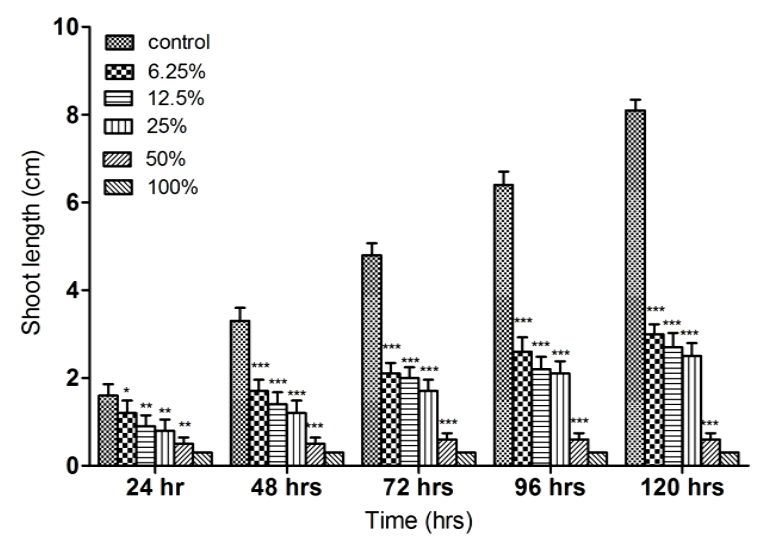

(c)

Figure 3. (a) Showing shoot growth of the Vicia faba seedlings treated for $120 \mathrm{~h}$ with leachate collected from Okhala in summer season. Data represent the mean $\pm \mathrm{SD}$. ${ }^{* *} \mathrm{p}<0.01,{ }^{* * *} \mathrm{p}<0.001$ vs. control; (b) showing shoot growth of the Vicia faba seedlings treated for $120 \mathrm{~h}$ with leachate collected from Okhala in Monsoon season. Data represent the mean \pm SD. ${ }^{*} \mathrm{p}<$ $0.05,{ }^{* *} \mathrm{p}<0.01,{ }^{* * *} \mathrm{p}<0.001$ vs. control; (c) showing shoot growth of the Vicia faba seedlings treated for $120 \mathrm{~h}$ with leachate collected from Okhala in Winter season. Data represent the mean $\pm \mathrm{SD} .{ }^{*} \mathrm{p}<0.05,{ }^{* *} \mathrm{p}<0.01,{ }^{* * *} \mathrm{p}<0.001$ vs. control. 


\subsection{Chlorophyll Levels}

The Chl $b$ content was increased at lower concentrations of the leachate collected in summer. With further increase in concentration of leachate, content of Chl b started declining and was reduced to 79.1\%, 63.1\% and $60.02 \%$ of control at $25 \%, 50 \%$ and $100 \%$ leachate concentration respectively. Even at the lower concentration of the leachate, content of Chl $a$ decreased. The Chl $a$ content was $29.2 \%$ and $27.7 \%$ of control in 50 and $100 \%$ leachate treated groups, respectively (Figure 4(a)-(b)).

Chlorophyll content in the leaf tissues of seedlings treated with landfill leachate collected in monsoon season showed slight changes as compared to summer samples. All the concentrations significantly increased the level of $C h l b$ in the leaf tissues of the treated seedlings. At 50\% and $100 \%$ leachate treatments the level of $C h l b$ was found to increase to 1.7 fold and 1.9 folds of control respectively. Whereas the levels of Chl $a$ were significantly reduced to $60.8 \%$ and $68.6 \%$ of control at $50 \%$ and $100 \%$ leachate concentrations respectively.

In the seedlings treated with leachate of winter season, at $50 \%$ and $100 \%$ of leachate concentrations Chl $a$ was found to be $31.7 \%$ and $27.3 \%$ of the control samples. The effect of leachate treatment on the Chl $a$ was more than the $C h l b$. While, the $C h l b$ content was found to be $80.1 \%$ and $68.4 \%$ at leachate concentration of $50 \%$ and $100 \%$ respectively.

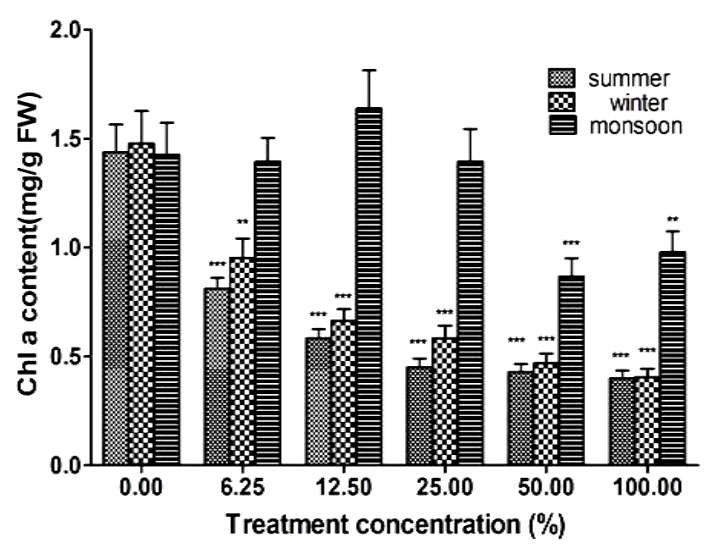

(a)

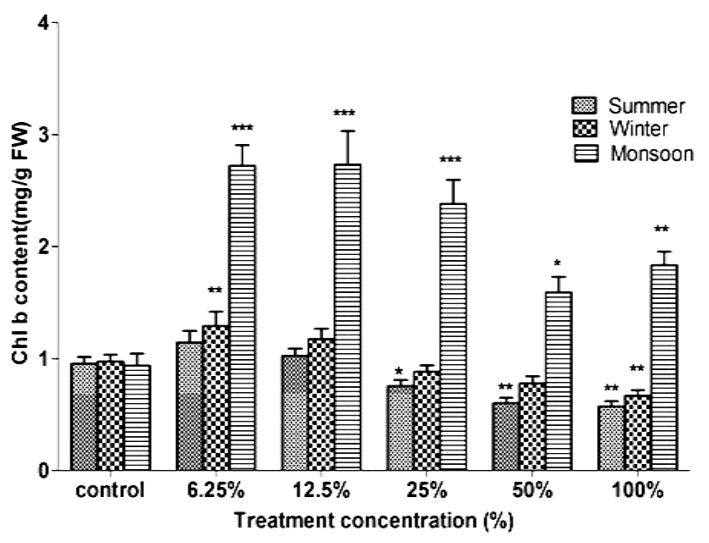

(b)

Figure 4. Variations in the level of Chl $a$ (a) and Chl b; (b) in the leaf tissues of Vicia faba seedlings treated with leachate sampled from Okhala landfill site in summer, monsoon and winter. Data represent the mean \pm SD. ${ }^{*} \mathrm{p}<0.05, \stackrel{* *}{\mathrm{p}}<0.01,{ }^{* * * *} \mathrm{p}<0.001$ vs. control.

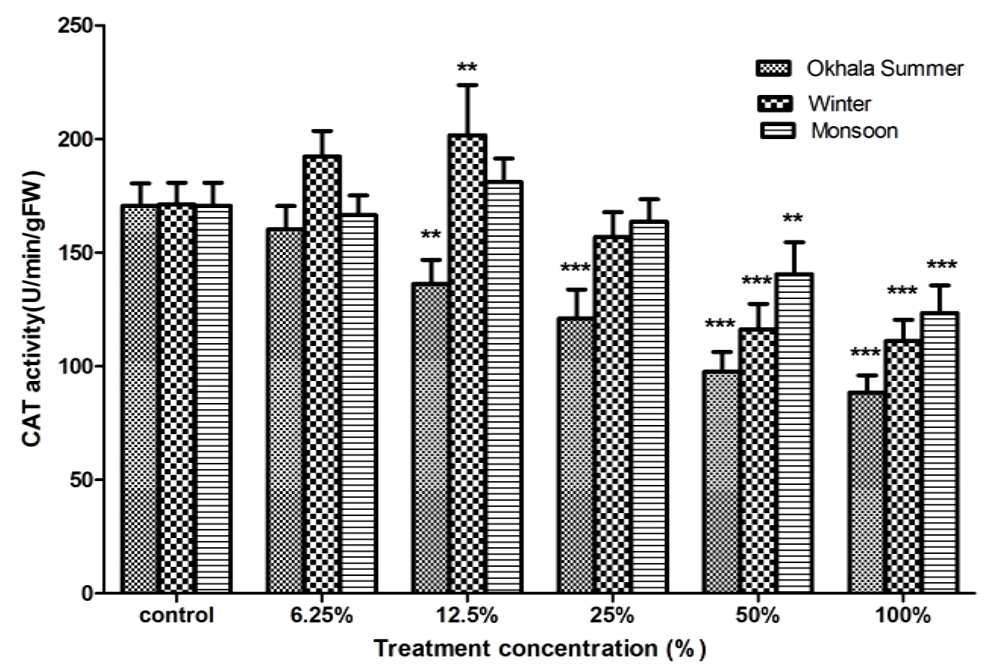

Figure 5. Showing variation in the CAT activity of samples treated with leachate collected in three seasons from Okhala landfill site on Vicia faba seedlings treated for 5-days. Results show mean $\pm \mathrm{SD}$. ${ }^{*} \mathrm{p}<0.05,{ }^{* *} \mathrm{p}<$ $0.01,{ }^{* * *} \mathrm{p}<0.001$ vs. control. 


\section{Antioxidant Enzymes}

\subsection{Catalase}

The CAT activity in the leaves of seedlings treated with landfill leachate collected in summer season decreased significantly in a dose dependent manner. After 6.25\% leachate treatment there was significant decrease in the CAT activity. At $50 \%$ of leachate treatment, the CAT activity was reduced up to $57.1 \%$ of the control which was further decreased up to $51.8 \%$ of control at $100 \%$ leachate treatment (Figure 5).

The CAT activity of the sample treated with leachate of monsoon season was not affected significantly in all the treatment concentrations of landfill leachate. In the lower concentration the CAT activity remained unaffected. But at $50 \%$ and $100 \%$ leachate concentrations the CAT activity was reduced significantly up to $82.4 \%$ and $72.4 \%$ of the control respectively.

However in the samples treated with leachate collected in winter it was observed that, at $12.5 \%$ leachate treatment, the CAT activity was increased up to $117.8 \%$ of the control where as at $50 \%$ and $100 \%$ leachate concentration, the CAT activity was reduced up to $67.9 \%$ and $64.9 \%$ of the control.

\subsection{Superoxide Dismutase}

In case of seedlings treated with leachate collected in summer the SOD activity increased at higher leachate treatment concentrations. It reached up to $117.41 \%$ and $121.43 \%$ of control in $50 \%$ and $100 \%$ leachate concentrations respectively. While SOD activity of the seedlings treated with landfill leachate collected in monsoon season showed different kind of results. There were no significant changes observed even at highest concentration $(100 \%)$ of leachate. On the other hand seedlings treated with leachate collected during winter season the SOD activity was $116.39 \%$ and $116.6 \%$ of control in $50 \%$ and $100 \%$ leachate concentrations respectively (Figure 6).

These results indicate that there is a clear variation in the SOD activity in the seedlings treated with leachate collected in different seasons. The SOD activity was mostly affected in the seedlings treated with leachate collected in summer season followed by winter.

\subsection{Lipid Peroxidation}

After the seedlings were exposed to different concentrations of leachate, the level of MDA was elevated in a dose dependent manner of leachate collected in summer, monsoon and winter season. The seedlings treated with leachate collected in summer season showed that the MDA levels in the leaf were elevated more significantly with increase in leachate concentration (Figure 7). MDA levels augmented to 1.7, 2.5, 2.5, 3 and 3.5 fold of control at the $6.25 \%, 12.5 \%, 25 \%, 50 \%$ and $100 \%$ respectively. Similarly seedlings treated with leachate of monsoon season, the level of MDA was significantly augmented by 1.9 and 2.5 fold at $50 \%$ and $100 \%$ respectively as compared to control group. While the seedlings treated with leachate collected in winter, MDA was significantly augmented at $25 \%$ to 2.5 fold of control and further increased with increase in the leachate concentration up to 3.0 fold of control at $100 \%$ leachate concentration.

\section{Discussion}

After analysis of the basic properties and chemical composition of the leachates collected in three seasons indicate that although landfill leachate is a mixture and contains different types of contaminants, there are some general underlying pollutants common to all landfill effluents [27]. These include a higher content of heavy metals and dissolved organic compounds as well as unbalanced nutrient composition for plant growth [21].

The leachate samples collected in all the three seasons affected the growth (root and shoot) in Vicia faba seedlings, the effects varied in a time and dose dependent manner when compared to control. Significant inhibition of the seed germination was observed at higher treatment of the leachate. These findings might have resulted from the damaged defence system and consequent unbalanced metabolism in case of higher concentration pollutants [28]. The increase in root and shoot length and chlorophyll content at the lower concentration of leachate over short period of treatment might be a result of the hormetic effect [28] [29]. This may represent an over compensation due to disruption of homeostasis or stimulation of defence reactions leading to a general activation of metabolism [30] [31]. Our findings suggest that with the increase in the concentration of exposure the ability of stress defence of plant system may decrease. Vegetation system could be tolerant to stress from the 


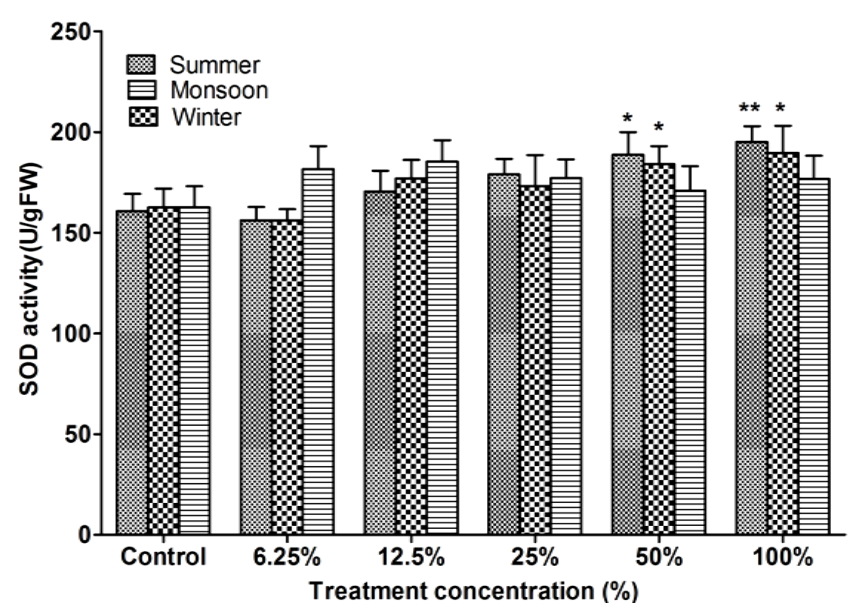

Figure 6. Showing variation in the SOD level in 5-days exposure to Vicia faba seedlings with leachate from Okhala landfill site collected in three seasons. Data represent the mean \pm SD of three seasons. ${ }^{*} \mathrm{p}<0.05,{ }^{* * *} \mathrm{p}<0.01$, vs. control.

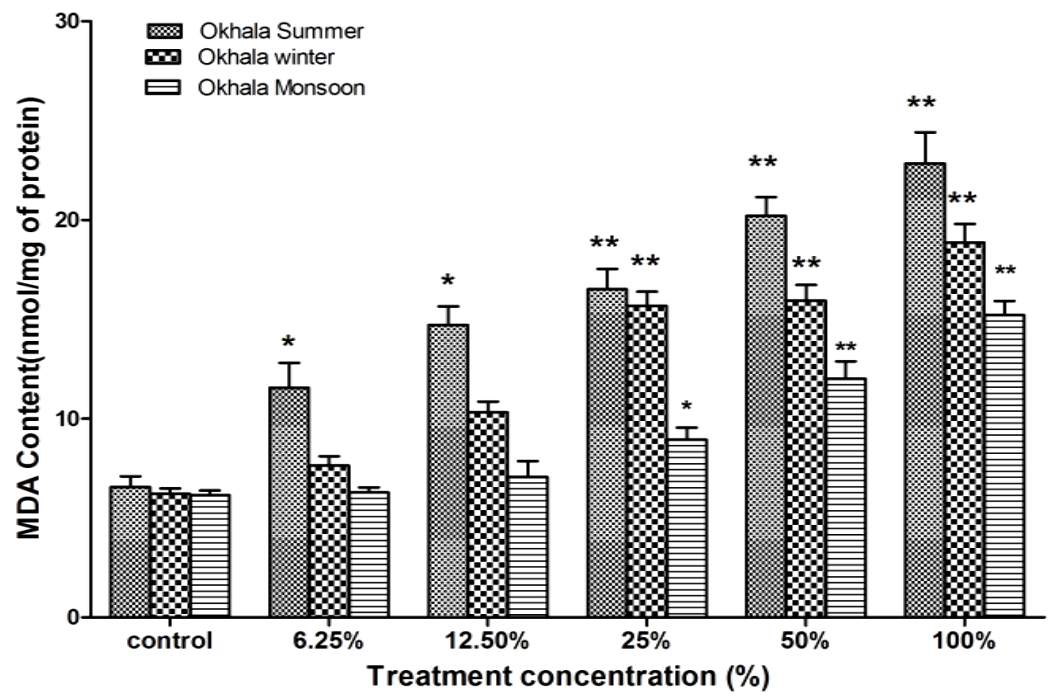

Figure 7. Showing variation in the level of lipid peroxidation (MDA content) in the leaves of $\mathrm{Vi}$ cia faba seedlings treated with Okhala landfill leachate of three seasons, for 5-days. Data represent the mean \pm SD of three seasons. ${ }^{*} \mathrm{p}<0.05,{ }^{* *} \mathrm{p}<0.01,{ }^{* * *} \mathrm{p}<0.001$ vs. control.

leachate samples at lower concentration but not at higher concentrations.

The plant growth, homeostasis and stress were all highly related to the controlled modulation of reactive oxygen species (ROS) [32]. Since the membrane lipids and proteins are the preferred targets of ROS in plants under environmental stress [33], they are considered to be reliable indicators of controlled modulation of ROS levels and oxidative stress [34] [35]. In the lower concentrations of leachate, oxidative damages were not observed but the stress became significant with increasing concentration of leachate which suggests that there is lower level of pollutants at the lower leachate concentration. These defence reactions may cleave ROS generated via elevated antioxidant defence system in the tissue. Whereas, exposure to higher level of leachate treatment which contains higher level of pollutants and induces the production of ROS, the capacity of antioxidant system was exceeded or inhibited. As a result of excessive ROS, it attacks lipids and proteins and the plant experienced substantial oxidative stress [21].

Additionally, the activities of antioxidant enzymes (SOD, CAT) were tested under the same treatment conditions for all the three seasons. SOD is a protein class that contains metals and catalyzes the dismutation of superoxide radical anions into $\mathrm{H}_{2} \mathrm{O}_{2}$ and molecular oxygen [36]. The elevated SOD activity in Vicia faba seedlings 
because of the pollutants in the leachate samples induced SOD to increase the generation of $\mathrm{H}_{2} \mathrm{O}_{2}$. Whereas for low concentration sample exposure, with lower pollutant levels, the plant cells presented endogenous protective effect, and the antioxidant enzymes were induced. Under these conditions, CAT was stimulated to scavenge the $\mathrm{H}_{2} \mathrm{O}_{2}$ that was produced because of which there was no oxidative stress. However, the levels of $\mathrm{H}_{2} \mathrm{O}_{2}$ were higher due to increased pollutant concentration at higher concentration of leachate, which exceeded the scavenging capacity of CAT. Because of this, CAT activity was inhibited and oxidative damage occurred in the plants treated with higher leachate concentration in all the three seasons but the inhibition was more in summer followed by winter and monsoon at same treatment concentrations. These results indicate that the plant cells showed endogenous protective effects, which induced the antioxidant enzymes to prevent against lipid peroxidation, at lower level of leachate concentration in all the three seasons. Our results are in line with the earlier studies [21] [37].

It has been reported earlier that most of the contaminants that are present in the leachate are toxic and are capable to induce mutations [38]. The potential of leachate to cause hazards to public health and water quality are well known [6] [39]. Beside these toxic elements, some nutrient elements are also present in the leachates [27]. In case of the leachate collected in summer and winter season, the high level of toxic organic compounds and heavy metals that are present in the leachate concealed the action of nutrient elements and showed inhibitory effects on growth as well as other parameters studied [16].

\section{Conclusion}

Present study confirms that landfill leachate may act as a physiological and cytotoxic agent in plant cells. It also implies that leachate in summer and winter season is more toxic as compared to that in monsoon season. It indicates that the mixture can result in the contamination of aquatic environment in the vicinity of the landfill even at dilute concentrations if the leachates are released without treatment and because of this the contaminated aquatic environment may pose a risk to the organisms exposed. It also suggests that the most important aspect for the treatment of landfill leachate is controlling its concentration which varies with respect to different seasons so that the proper management of landfills is ensured.

\section{Acknowledgements}

Authors are thankful to technical staff of the Central Instrumentation Facility (CIF), School of Environmental Sciences (SES), Jawaharlal Nehru University (JNU), New Delhi for their help in analysis and the University Grants Commission (UGC) for providing fellowship.

\section{References}

[1] Mukherjee, S., Mukhopadhyay, S., Hashim, M.A. and Gupta, B.A. (2015) Contemporary Environmental Issues of Landfill Leachate: Assessment and Remedies. Critical Reviews in Environmental Science and Technology, 45, 472590. http://dx.doi.org/10.1080/10643389.2013.876524

[2] Christensen, T.H., Bjerg, P.P.L., Jensen, D.L., Christensen, A., Baum, A., Albrechtsen, H.J. and Heron, H. (2001) Biochemistry of Landfill Leachate Plumes. Applied Geochemistry, 16, 659-718. http://dx.doi.org/10.1016/S0883-2927(00)00082-2

[3] Sanchez-Chardi, A. and Nadal, J. (2007) Bioaccumulation of Metals and Effects of Landfill Pollution in Small Mammals. Chemosphere, 68, 703-711. http://dx.doi.org/10.1016/j.chemosphere.2007.01.042

[4] Pivato, A. and Gaspari, L. (2006) Acute Toxicity Test of Leachates from Traditional and Sustainable Landfills Using Luminescent Bacteria. Waste Management, 26, 1148-1155. http://dx.doi.org/10.1016/j.wasman.2005.10.008

[5] Sang, N., Li, G. and Xin, X. (2006) Municipal Landfill Leachate Induces Cytogenetic Damage in Root Tips of Hordeum vulgare. Ecotoxicology and Environmental Safety, 63, 469-473. http://dx.doi.org/10.1016/j.ecoenv.2005.02.009

[6] Schrab, G.E., Brown, K.W. and Donnelly, K.C. (1993) Acute and Genetic Toxicity of Municipal Landfill Leachate. Water, Air and Soil Pollution, 69, 99-112. http://dx.doi.org/10.1007/BF00478351

[7] Kjeldsen, P., Barla, M. A., Rooker, A.P., Baun, A., Ledin, A. and Christensen, T.H. (2002) Present and Long-Term Composition of MSW Landfill Leachate: A Review. Critical Reviews in Environmental Science and Technology, 32, 297-336. http://dx.doi.org/10.1080/10643380290813462

[8] Slack, R.J., Gronow, J.R. and Voulvoulis, N. (2005) Household Hazardous Waste in Municipal Landfills: Contaminants in Leachate. Science of the Total Environment, 337, 119-137. http://dx.doi.org/10.1016/j.scitotenv.2004.07.002 
[9] Kalcikova, G., Vavrova, M.J., Zagorc-Koncan, T. and Gotvajn, A.Z. (2011) Seasonal Variations in Municipal Landfill Leachate Quality. Management of Environmental Quality: An International Journal, 22, 612-619. http://dx.doi.org/10.1108/14777831111159734

[10] Matejczyk, M., Płaza, G.A., Nałecz-Jawecki, G., Ulfig, K. and Markowska-Szczupak, A. (2011) Estimation of the Environmental Risk Posed by Landfills Using Chemical, Microbiological and Ecotoxicological Testing of Leachates. Chemosphere, 82, 1017-1023. http://dx.doi.org/10.1016/j.chemosphere.2010.10.066

[11] Trankler, J., Visvanathan, C., Kuruparan, P. and Tubtimthai, O. (2005) Influence of Tropical Seasonal Variations on Landfill Leachate Characteristics Results from Lysimeter Studies. Waste Management, 25, 1013-1020. http://dx.doi.org/10.1016/j.wasman.2005.05.004

[12] Visvanathan, J., Trankler, P., Kuruparan, Q. and Qin, X.N. (2003) Influence of Landfill Operation and Waste Composition on Leachate Control: Lysimeter Experiments under Tropical Conditions. Proceedings of the 2nd Asia Pacific Landfill Symposium, Seoul, 441-447.

[13] Mangimbulude, J.C., Boris, M., Breukelen, V., Krave, A.S., Nico, M. and Wilfred, F.M. (2009) Seasonal Dynamics in Leachate Hydrochemistry and Natural Attenuation in Surface Run-Off Water from a Tropical Landfill. Waste Management, 29, 829-838. http://dx.doi.org/10.1016/j.wasman.2008.06.020

[14] Tatsi, A.A. and Zouboulis, A.I. (2002) A Field Investigation of the Quantity and Quality of Leachate from a Municipal Solid Waste Landfill in a Mediterranean Climate (Thessaloniki, Greece). Advances in Environmental Research, 6, 207219. http://dx.doi.org/10.1016/S1093-0191(01)00052-1

[15] Thomas, D.J.L., Tyrrel, S.F., Smith, F. and Farrow, S. (2009) Bioassays for the Evaluation of Landfill Leachate Toxicity. Journal of Toxicology and Environmental Health, Part B: Critical Reviews, 12, 83-105. http://dx.doi.org/10.1080/10937400802545292

[16] Li, G.K., Yun, Y., Li, H.Y. and Sang, N. (2008) Effect of Landfill Leachate on Cell Cycle, Micronucleus, and Sister Chromatid Exchange in Triticum aestivum. Journal of Hazardous Materials, 155, 10-16.

[17] Sang, N. and Li, G.K. (2004) Genotoxicity of Municipal Landfill Leachate on Root Tips of Vicia faba. Mutation Research/Genetic Toxicology and Environmental Mutagenesis, 560, 159-165. http://dx.doi.org/10.1016/j.mrgentox.2004.02.015

[18] Kumar, N., Bauddh, K., Kumar, S., Dwivedi, N., Singh, D.P. and Barman, S.C. (2012) Extractibility and Phytotoxicity of Heavy Metals Present in Petrochemical Industry Sludge. Clean Technologies and Environmental Policy, 15, 10331039. http://dx.doi.org/10.1007/s10098-012-0559-1

[19] Xi, D.L., Sun, Y.S. and Liu, X.Y. (1996) Environment Monitoring. Higher Education Press, Beijing.

[20] Federation, Water Environmental and American Public Health Association (2005) Standard Methods for the Examination of Water and Wastewater. American Public Health Association (APHA), Washington DC.

[21] Sang, N., Han, M., Li, G.K. and Huang, M.Z. (2010) Landfill Leachate Affects Metabolic Responses of Zea mays Seedlings. Waste Management, 30, 856-862. http://dx.doi.org/10.1016/j.wasman.2010.01.023

[22] Janero, D. and David, R. (1990) Malondialdehyde and Thiobarbituric Acid-Reactivity as Diagnostic Indices of Lipid Peroxidation and Peroxidative Tissue Injury. Free Radical Biology and Medicine, 9, 515-540. http://dx.doi.org/10.1016/0891-5849(90)90131-2

[23] El-Moshaty, F.I.B., Pike, S.M., Novacky, A.J. and Sehgal, O.P. (1993) Lipid Peroxidation and Superoxide Production in Cowpea (Vigna unguiculata) Leaves Infected with Tobacco Ringspot Virus or Southern Bean Mosaic Virus. Physiological and Molecular Plant Pathology, 43, 109-119. http://dx.doi.org/10.1006/pmpp.1993.1044

[24] Zhu, G.L., Zhong, H.W. and Zhang, A.Q. (1990) The Experiments of Plant Physiology. The Peking University Press, Beijing.

[25] Zhang, Z.L. (1990) The Experimental Methods of Plant Physiology. Higher Education Press, Beijing, 51-53.

[26] The Gazette of India (2000) Municipal Solid Waste (Management and Handling) Rules. Notification Issued by Ministry of Environment and Forests, Government of India.

[27] Jones, D.L., Williamson, K.L. and Owen, A.G. (2006) Phytoremediation of Landfill Leachate. Waste Management, 26, 825-837. http://dx.doi.org/10.1016/j.wasman.2005.06.014

[28] Cargnelutti, D., Tabaldi, L.A., Spanevell, R.M., Jucoski, G., de Oliveira, V., Battisti, M., Redin, C.E., Linares, V.L., Dressler, E.M., de Moraes, F.T., Nicoloso, V.M. and Morsch, M.R. (2006) Mercury Toxicity Induces Oxidative Stress in Growing Cucumber Seedlings. Chemosphere, 65, 999-1006. http://dx.doi.org/10.1016/j.chemosphere.2006.03.037

[29] Calabreseci, E.J. (1999) Evidence That Hormesis Represents an Overcompensation Response to a Disruption in Homeostasis. Ecotoxicology and Environmental Safety, 42, 135-137. http://dx.doi.org/10.1006/eesa.1998.1729

[30] Barcelo, J. and Poschenrieder, C. (2002) Fast Root Growth Responses, Root Exudates, and Internal Detoxification as Clues to the Mechanisms of Aluminium Toxicity and Resistance: A Review. Environmental and Experimental Botany, 
48, 75-92. http://dx.doi.org/10.1016/S0098-8472(02)00013-8

[31] Calabrese, E.J. and Blain, R. (2005) The Occurrence of Hormetic Dose Responses in the Toxicological Literature, the Hormesis Database: An Overview. Toxicology and Applied Pharmacology Review, 202, 289-301. http://dx.doi.org/10.1016/j.taap.2004.06.023

[32] Apel, K. and Hirt, H. (2004) Reactive Oxygen Species: Metabolism, Oxidative Stress, and Signal Transduction. Annual Review of Plant Biology, 55, 373-399. http://dx.doi.org/10.1146/annurev.arplant.55.031903.141701

[33] Prasad, T.K. (1996) Mechanisms of chilling-Induced Oxidative Stress Injury and Tolerance in Developing Maize Seedlings: Changes in Antioxidant System, Oxidation of Proteins and Lipids, and Protease Activities. The Plant Journal, 10, 1017-1026. http://dx.doi.org/10.1046/j.1365-313X.1996.10061017.x

[34] Halliwell, B. and Gutteridge, J.M.C. (1993) Free Radicals in Biology and Medicine. Clarendon Press, Oxford.

[35] Meena, R. and Paulraj, R. (2012) Oxidative Stress Mediated Cytotoxicity of $\mathrm{TiO}_{2}$ Nano Anatase in Liver and Kidney of Wistar Rat. Toxicological \& Environmental Chemistry, 94, 146-163. http://dx.doi.org/10.1080/02772248.2011.638441

[36] Scandalios, J.G. (1993) Oxygen Stress and Superoxide Dismutases. Plant Physiology, 101, 1-7.

[37] Zhu, N., Ku, T.T., Li, G.K. and Sang, N. (2013) Evaluating Biotoxicity Variations of Landfill Leachate as Penetrating through the Soil Column. Waste Management, 33, 1750-1757. http://dx.doi.org/10.1016/j.wasman.2013.02.018

[38] Bakare, A.A., Mosuro, A.A. and Osibanjo, O. (2000) Effect of Stimulated Leachate on Chromosomes and Mitosis in Roots of Allium cepa L. Environmental Biology, 21, 251-260.

[39] Li, G.K., Sang, N. and Guo, D.S. (2006) Oxidative Damage Induced in Hearts, Kidneys and Spleens of Mice by Landfill Leachate. Chemosphere, 65, 1058-1063. http://dx.doi.org/10.1016/j.chemosphere.2006.02.056 